\section{Penggunaan Animasi Timelapse Citra Satelit Sebagai Media Pembelajaran Dampak Perubahan Iklim}

Trida Ridho Fariz

trida.ridho.fariz@mail.unnes.ac.id

\begin{abstract}
Abstrak
Proses pembelajaran perubahan iklim terhitung sulit dikarenakan materinya bersifat abstrak, sehingga dibutuhkan sebuah media pelajaran yang menarik. Aplikasi geemap adalah timelapse animation generator berbasis Google Earth Engine, yang mana mampu membuat animasi timelapse citra satelit tanpa proses penyuntingan script.

Pembuatan animasi timelapse citra satelit menjadi lebih mudah menggunakan aplikasi geemap. Studi kasus yang dipilih adalah perubahan garis pantai di bagian timur Teluk Semarang, karena dampak yang terjadi sangat masif sehingga terlihat jelas perubahannya melalui citra satelit. Adapun parameter yang digunakan untuk membuat animasi timelapse adalah komposit citra SWIR/NIR/Red, hal ini dikarenakan komposit tersebut dinilai paling baik untuk memvisualisasikan perubahan garis pantai.
\end{abstract}

Kata kunci: animasi timelapse, media pembelajaran, perubahan iklim, citra satelit landsat, google earth engine

Trida Ridho Fariz ${ }^{1}$, Nurhafizah ${ }^{2}$

Ilmu Lingkungan. Jurusan IPA Terpadu. Universitas Negeri Semarang ${ }^{1}$ MAN Insan Cendekia Sambas ${ }^{2}$ 


\section{PENDAHULUAN}

Perubahan iklim memberikan dampak negatif yang nyata bagi kehidupan. Dampak tersebut meliputi peningkatan suhu, kenaikan muka air laut yang mana akan meningkatkan potensi bencana. Pengurangan penyebab perubahan iklim dan risikonya bisa dilakukan melalui pendidikan. Pendidikan yang berkaitan dengan perubahan iklim sudah diimplementasikan di Indonesia dalam mata pelajaran IPA Terpadu di kelas VII SMP dan mata pelajaran Geografi di kelas XI SMA (Sutiyati dkk, 2015; Hastuti dkk, 2017). Proses pembelajaran terhitung sulit dikarenakan materi perubahan iklim ini bersifat abstrak, yang mana mempelajari proses seperti dampak perubahan iklim yang terjadi tidak dapat diamati secara langsung (Sutiyati dkk, 2015). Sehingga dibutuhkan sebuah media pembelajaran yang membantu pengajar untuk menyampaikan materi perubahan iklim.

Media pembelajaran berbasis penginderaan jauh merupakan solusi untuk pembelajaran mengenai dampak perubahan iklim. Melalui penginderaan jauh siswa dapat melihat fenomena dipermukaan bumi sesesuai aslinya yang mana ini akan meningkatkan pemahaman siswa mengenai konsep wilayah dibandingkan media konvensional (Khoiruddin dkk, 2016). Penggunaan penginderaan jauh sebagai media pembelajaran di Indonesia masih terbatas pada penggunaan single temporal saja. Padahal data penginderaan jauh memiliki resolusi temporal yang tinggi sehingga kita dapat melihat perubahan fenomena alam dibumi seperti dampak perubahan iklim.

Hadirnya platform bernama Google Earth Engine (GEE) sangat membantu untuk proses pembuatan media pembelajaran dari data penginderaan jauh multi temporal. GEE mempunyai kelebihan seperti akses data yang sangat besar dan pengolahan data berbasis cloud, sehingga proses analisis dan visualisasi geo-big data dapat dilakukan tanpa menggunakan super komputer (Tamiminia et al, 2020). Hal ini membuat beberapa analisis multitemporal seperti pemetaan hutan dan kekeringan dalam skala global dapat dilakukan dalam waktu singkat. Selain itu output dari GEE bisa disajikan dalam bentuk animasi berformat gif, sehingga sangat cocok digunakan sebagai media pembelajaran untuk materi yang abstrak (Novianti \& Shodikin, 2018; Setiawan, 2020).

Pengolahan dan visualisasi data pada GEE dilakukan dengan bahasa pemograman yaitu Java. Hal ini bisa menjadi halangan mengingat para guru umumnya memiliki kemampuan pemograman yang masih minim (Setiawan, 2020). Solusi tersebut bisa diatasi dengan aplikasi berbasis GEE yang dikembangkan oleh $\mathrm{Wu}$ et al (2020), yang membantu pembuatan animasi dari data penginderaan jauh dari GEE tanpa proses script. Output dari aplikasi tersebut adalah animasi timelapse dalam format .gif. Oleh karena itu, artikel ini akan membahas penggunaan aplikasi tersebut sebagai media pembelajaran.

\section{METODE}

Animasi timelapse citra satelit pada artikel ini dibuat menggunakan aplikasi yang dikembangkan oleh $\mathrm{Wu}$ et al (2020) yaitu geemap. Aplikasi ini bisa diakses secara online melalui geemap.herokuapp.com/voila/render/timelapse.ipynb.

Metode yang digunakan dalam penelitian ini antara lain studi literatur dan analisis deskriptif. Studi literatur bertujuan untuk mendapatkan studi kasus dampak perubahan iklim yang akan dijadikan media pembelajaran. Analisis deskriptif digunakan untuk menggambarkan masalah dan solusi yang terjadi, yang mana hal lebih diimplementasikan pada pembahasan geemap sebagai media pembelajaran.

\section{HASIL DAN PEMBAHASAN}

\section{Penentuan Parameter}

Penentuan paramater meliputi penentuan studi kasus, komposit dan rentang waktu yang akan dibuat animasi timelapse. Penentuan studi kasus harus memiliki kriteria yaitu dampak perubahan iklim harus terlihat jelas kenampakan dan perubahannya. Jika dampak perubahan 
iklim yang dimaksud adalah kerusakan akibat putting beliung, tentu akan sulit terlihat kenampakannya karena sumber data yang digunakan adalah citra satelit Landsat yang memiliki resolusi spasial $30 \mathrm{~m}$. Sehingga pemilihan lokasi harus sesuai dengan skala sumber data.

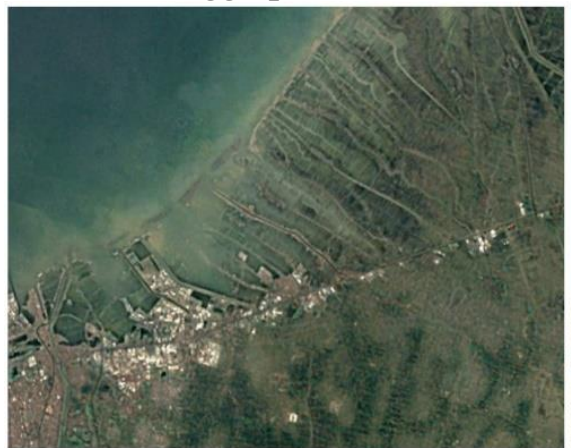

Tahun 2001

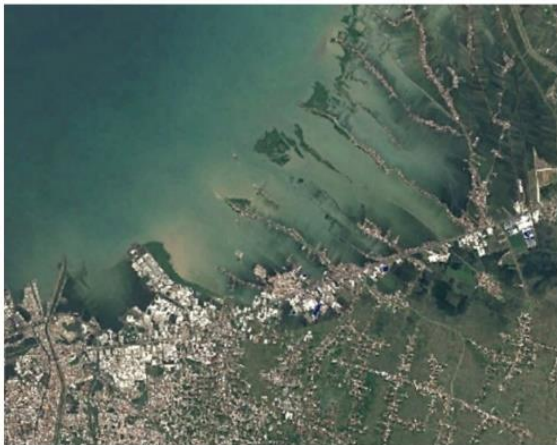

Tahun 2020

Gambar 1. Kenampakan perubahan garis pantai di timur Teluk Semarang

Studi kasus yang dipilih adalah perubahan garis pantai. Pemilihan garis pantai dikarenakan dampak perubahan iklim akan terasa pada daerah pesisir (Rositasari dkk, 2011). Wilayah yang dipilih adalah bagian timur Teluk Semarang, yang secara administrasi berada di Kecamatan Genuk, Kota Semarang dan Kecamatan Sayung, Kabupaten Demak. Wilayah ini dipilih karena dalam kurun waktu 2006 - 2016, diestimasi bahwa kenaikan perairan di Kota Semarang sebesar $+5,52 \mathrm{~mm} /$ tahun dan perubahan garis pantai akibat abrasi terbesar berada di Kecamatan Sayung, Kabupaten Demak (Setianingsih dkk, 2018). Selain itu kenaikan muka air laut pada wilayah ini memberi dampak terhadap ekosistem lebih besar dibandingkan Kota Pekalongan dan DKI Jakarta. Dampak terhadap ekosistem tersebut meliputi erosi pantai, banjir rob, kerusakan bangunan, meningkatkan masalah sanitasi dan masalah kesehatan lingkungan (Marfai, 2014). Pada Gambar 1, terlihat bahwa perubahan garis pantai di bagian timur Teluk Semarang cukup masif.

Penentuan komposit juga merupakan hal yang penting dalam animasi timelapse citra satelit Landsat untuk media pembelajaran. Komposit citra merupakan visualisasi citra satelit dengan melibatkan 3 saluran. Sebelum menentukan suatu komposit hal pertama yang harus dipahami adalah karakteristik dari band suatu citra penginderaan jauh. Seperti pada Tabel 1 yang menunjukkan bahwa band NIR (inframerah dekat) sangat peka terhadap vegetasi, sehingga cocok digunakan untuk kajian vegetasi (NASA, 2013; Purwadhi \& Sanjoto, 2008).

Setelah memahami karakteristik respon setiap band, selanjutnya adalah menentukan komposit yang akan digunakan. Setiap komposit citra memiliki keunggulan yang berbeda-beda, sebagai contoh adalah komposit true color yang terdiri dari band red, green, blue yang mempu menunjukkan kenampakan bumi dengan warna sebenarnya, komposit false red color yang terdiri dari NIR, red, green yang sangat peka dengan kenampakan vegetasi walaupun menunjukkan warna vegetasi yang merah menyala (Herbei \& Sala, 2016). Selain itu, ada juga komposit false green color yang terdiri dari SWIR-1, NIR dan red yang umumnya digunakan untuk membedakan lahan terbangun dan bukan lahan terbangun (Suwarsono \& Khomarudin, 2014).

Tabel 1. Karakteristik band pada citra satelit Landsat

\begin{tabular}{|c|c|c|c|c|}
\hline \multirow{2}{*}{ Band } & \multirow{2}{*}{ Karakteristik } & \multicolumn{3}{|c|}{ Band } \\
\hline & & Landsat 5 & Landsat 7 & Landsat 8 \\
\hline Coastal & Band coastal, peka terhadap aerosol & - & - & Band 1 \\
\hline Blue & Band biru, peka terhadap tubuh air & Band 1 & Band 1 & Band 2 \\
\hline Green & Band hijau, peka terhadap vegetasi & Band 2 & Band 2 & Band 3 \\
\hline Red & Band merah, peka terhadap vegetasi & Band 3 & Band 3 & Band 4 \\
\hline NIR & $\begin{array}{l}\text { Band inframerah dekat, sangat peka } \\
\text { terhadap vegetasi }\end{array}$ & Band 4 & Band 4 & Band 5 \\
\hline SWIR-1 & $\begin{array}{l}\text { Band inframerah dekat untuk diferensiasi } \\
\text { vegetasi, bangunan dan salju }\end{array}$ & Band 5 & Band 5 & Band 6 \\
\hline
\end{tabular}




\begin{tabular}{llccc}
\hline SWIR-2 & $\begin{array}{l}\text { Band termal untuk mendeteksi litologi dan } \\
\text { bentuk lahan }\end{array}$ & Band 7 & Band 7 & Band 7 \\
\hline Pan & Band dengan resolusi spasial 15m & - & Band 8 & Band 8 \\
\hline Cirrus & Band yang sangat peka terhadap awan & - & - & Band 9 \\
\hline LWIR & Band termal untuk mendeteksi suhu & Band 6 & Band 6 & Band 10 \\
\hline
\end{tabular}

Komposit green false color kami pilih untuk digunakan sebagai parameter media pembelajaran ini. Komposit true color menunjukkan warna obyek yang sebenarnya, tetapi kurang jelas untuk membedakan kenampakan daratan yang sudah tergenang air laut. Hal tersebut dikarenakan sedimentasi hasil erosi pantai yang membuat perairan berwarna coklat yang mirip dengan daratan. Untuk komposit false red color sangat kontras membedakan vegetasi, tetapi vegetasi yang dilapangan bewarna hijau tua diekspresikan dalam warna merah menyala sehingga dikhawatirkan pengguna tidak dapat menginterpretasi obyek dengan baik akibat perbedaan warna (Gambar 2). Komposit false green color sangat tegas membedakan obyek air dan bukan air, selain itu vegetasi juga masih dieskpresikan dalam warna hijau sehingga pengguna asumsikan masih bisa menginterpretasikan obyek.

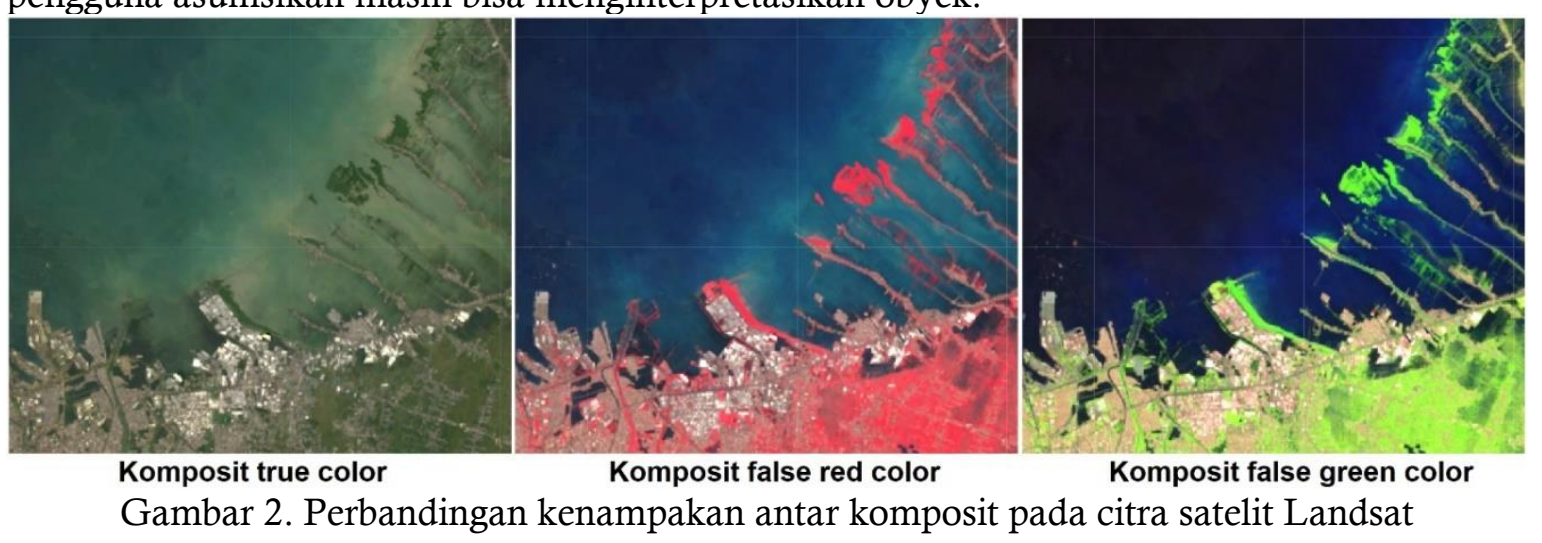

Tahapan pembuatan

Pembuatan animasi timelapse citra satelit Landsat melalui laman https://geemap.herokuapp.com/voila/render/timelapse.ipynb. Pada muka peta dilaman tersebut terdapat beberapa menu utama yang tersaji pada Gambar 3.

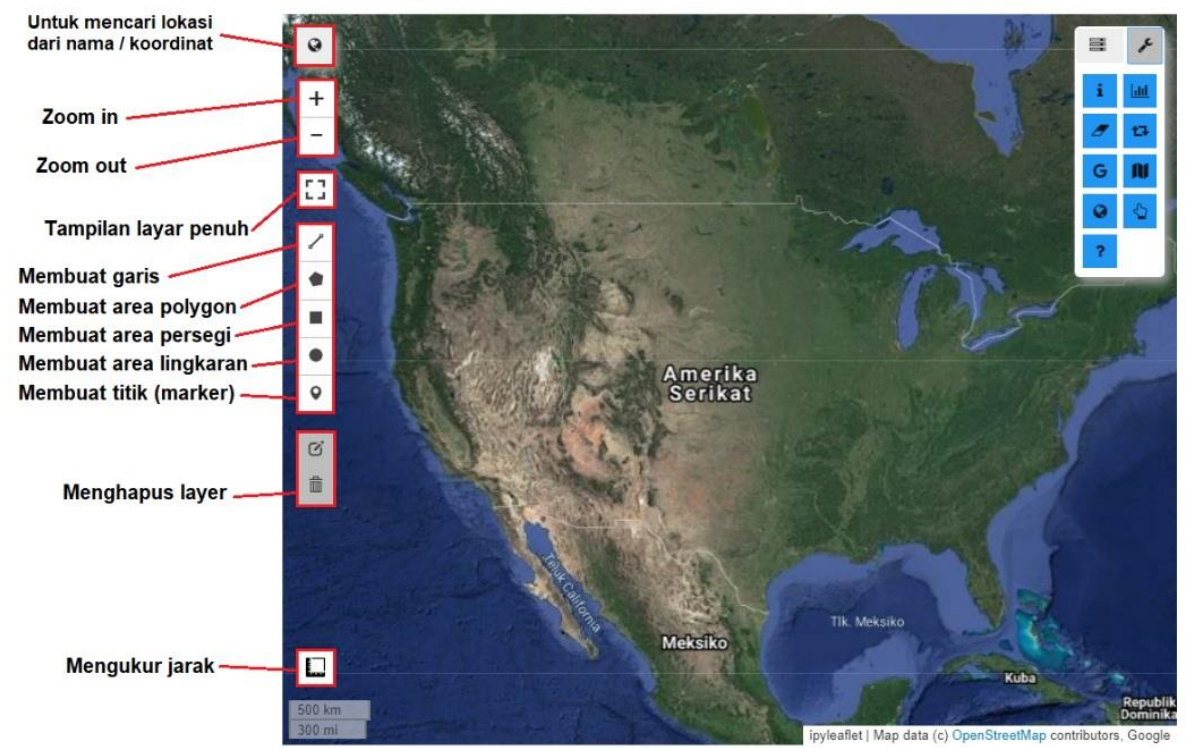

Gambar 3. Tampilan muka peta geemap

Proses untuk pembuatan animasi timelapse antara lain:

1. Geser dan zoom ke area yang diinginkan, atau klik ikon globe di pojok kiri atas untuk mencari lokasi. 
2. Gunakan alat gambar untuk menggambar persegi panjang di mana saja di peta, sebagai contoh di Gambar 4 menggunakan area persegi (rectangle).

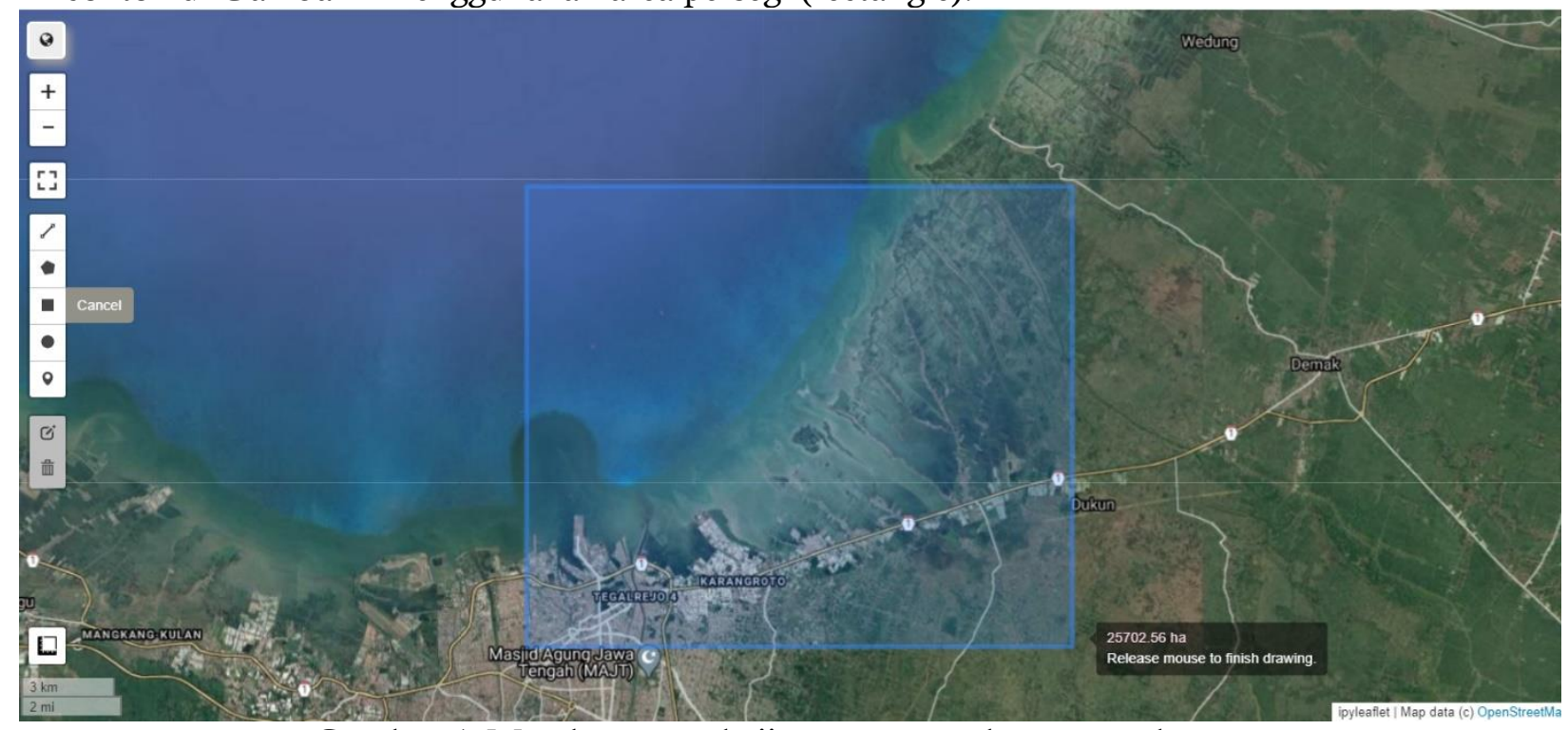

Gambar 4. Membuat area kajian menggunakan rectangle

3. Sesuaikan parameter seperti judul, tahun dan RGB combo (komposit citra). Kami mengunakan komposit SWIR-1, NIR, Red (Gambar 5). Untuk Frame per second kami menggunakan 3, semakin tinggi Frame per second maka transisi gambar akan semakin cepat. Untuk tahun dimulai dari 1990 dan rentang bulan dari 4 ke 11. Hal ini dikarenakan ketersediaan dan kualitas data. Data dengan tutupan awan yang banyak aka mengganggu kenampakan garis pantai. Oleh karena itu kami menggunakan waktu diluar musim hujan (desember - februari) untuk meminimalisir tutupan awan.

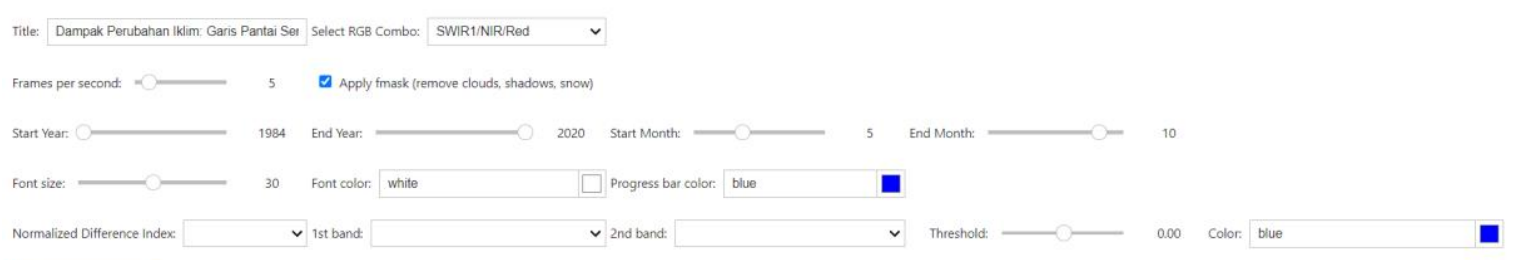

Gambar 5. Pengaturan parameter

4. Klik tombol Create Timelapse untuk membuat animasi timelapse.

5. Setelah timelapse telah ditambahkan ke peta, klik hyperlink di bagian akhir jika Anda ingin mengunduh GIF.

Hasil dari animasi timelapse di artikel ini bisa dilihat di tautan bit.ly/PantaiSemarang. Pada animasi timelapse ini terlihat masih ada area yang berwarna gelap akibat tutupan awan dan area (strip) berbeda warna akibat SLC-off. SLC-off adalah kerusakan scan line corrector pada Landsat 7 pada Mei 2003, yang membuat semua data citra Landsat 7 terdapat gap (Asare et al, 2020). Hal tersebut bisa diatasi dengan mengisi gap tersebut dengan citra lain dibeda waktu perekaman, sehingga terlihat area (strip) yang perbedaan warna.

Media pembelajaran berbentuk animasi timelapse ini perlu diuji sebelum benar-benar disebut sebagai media pembelajaran. Proses pengujian bisa dilakukan dengan uji kelayakan media dan materi dari ahli maupun uji coba produk dan tes pemahaman (Simanungkalit dkk, 2019; Wardana dkk, 2019; Hanim dkk, 2019). Proses pengujian ini merupakan saran dari kami sebagai pengembangan artikel ini.

\section{SIMPULAN}

Pembuatan animasi timelapse citra satelit menjadi lebih mudah menggunakan aplikasi 
geemap. Studi kasus yang dipilih adalah perubahan garis pantai di bagian timur Teluk Semarang, karena dampak yang terjadi sangat masif sehingga terlihat jelas perubahannya melalui citra satelit. Adapun parameter yang digunakan untuk membuat animasi timelapse adalah komposit citra SWIR/NIR/Red, hal ini dikarenakan komposit tersebut dinilai paling baik untuk memvisualisasikan perubahan garis pantai.

\section{DAFTAR PUSTAKA}

Asare, Y. M., Forkuo, E. K., Forkuor, G., \& Thiel, M. (2020). Evaluation of gap-filling methods for Landsat 7 ETM+ SLC-off image for LULC classification in a heterogeneous landscape of West Africa. International Journal of Remote Sensing, 41(7), 2544-2564.

Hanim, F., Sumarmi, S., \& Amirudin, A. (2016). Pengaruh penggunaan multimedia pembelajaran interaktif penginderaan jauh terhadap hasil belajar geografi. Jurnal Pendidikan: Teori, Penelitian, dan Pengembangan, 1(4), 752-757.

Hastuti, D., \& Muryani, C. (2017). Mitigasi, Kesiapsiagaan, dan Adaptasi Masyarakat Terhadap Bahaya Kekeringan, Kabupaten Grobogan (Implementasi Sebagai Modul Konstektual Pembelajaran Geografi SMA Kelas X Pokok Bahasan Mitigasi Bencana). GeoEco, 3(1).

Herbei, M., \& Sala, F. (2016). Classification of land and crops based on satellite images Landsat 8: case study SD Timisoara. Bulletin UASVM series Agriculture, 73(1), 29-34.

Khoiruddin, A., Pargito, P., \& Miswar, D. (2016). Perbandingan Hasil Belajar Siswa Menggunakan Media Google Earth Dan Media Konvensional. Jurnal Penelitian Geografi, $4(1)$.

Marfai, M. A. (2014). Impact of sea level rise to coastal ecology: A case study on the northern part of java island, Indonesia. Quaestiones Geographicae, 33, 107-114.

NASA. 2013. LDCM (Landsat Data Continuity Mission) Press Kit. Diakses dari https://www.nasa.gov

Novianti, A., \& Shodikin, A. (2018). Pengembangan Bahan Ajar Kalkulus Diferensial Berbasis Animasi dengan Pendekatan Kontekstual dan Kearifan Lokal. De Fermat: Jurnal Pendidikan Matematika, 1(2), 12-18.

Purwadhi, S. H., \& Sanjoto, T. B. (2008). Pengantar interpretasi citra penginderaan jauh. Lembaga Penerbangan dan Antariksa Nasional dan Jurusan Geografi Universitas Negeri Semarang.

Rositasari, R., Setiawan, W. B., \& Supriadi, I. H. (2011). Kajian dan prediksi kerentanan pesisir terhadap perubahan iklim: studi kasus di Pesisir Cirebon. Jurnal Ilmu dan Teknologi Kelautan Tropis, 3(1), 53.

Setianingsih, W., Sasmito, B., \& Bashit, N. (2018). Analisis Sea Level Rise di Laut Utara Jawa Terhadap Perubahan Garis Pantai Wilayah Demak Pada Tahun 2006-2016. Jurnal Geodesi Undip, 7(2), 53-64.

Setiawan, R. (2020). Rancang Bangun Media Pembelajaran Berbasis Android Tanpa Coding Semudah Menyusun Puzzle. Jurnal Sistem Informasi dan Sains Teknologi, 2(2).

Simanungkalit, K., Damanik, M. R. S., \& Lubis, D. P. (2019). Optimalisasi Foto Udara Unmanned Aerial Vehicle (UAV) Sebagai Media Pembelajaran Penginderaan Jauh. Tunas Geografi, 8(1), 45-58.

Sutiyani, S., Nurhayati, S., \& Widiyatmoko, A. (2015). Pengaruh Model Pembelajaran Role Playing Pada Hasil Belajar Siswa SMP Kelas VII Tema Global Warming Dan Dampaknya Bagi Ekosistem. Unnes Science Education Journal, 4(3).

Suwarsono., \& Khomarudin M. R. (2014). Deteksi wilayah permukiman pada bentuklahan 
vulkanik menggunakan citra Landsat-8 OLI berdasarkan parameter Normalized Difference Build-up Index (NDBI). Prosiding Seminar Penginderaan Jauh 2014, pp. 345-356.

Tamiminia, H., Salehi, B., Mahdianpari, M., Quackenbush, L., Adeli, S., \& Brisco, B. (2020). Google Earth Engine for geo-big data applications: A meta-analysis and systematic review. ISPRS Journal of Photogrammetry and Remote Sensing, 164, 152-170.

Wardana, F., Utaya, S., \& Bachri, S. (2019). Media Penginderaan Jauh Berbasis Android dalam Pembelajaran Geografi SMA. Jurnal Pendidikan: Teori, Penelitian, dan Pengembangan, 4(7), 863-868.

Wu, Q., (2020). geemap: A Python package for interactive mapping with Google Earth Engine. The Journal of Open Source Software, 5(51), 2305. 
ISBN 978-623-6967-68-3
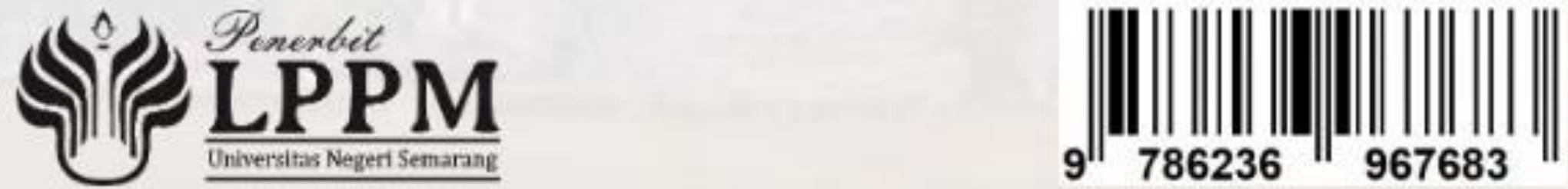